\title{
Mass Violence and the Continuum of Destruction: A study of C. P. Taylor's Good
}

\author{
James Hardie-Bick ${ }^{1}$
}

Published online: 12 May 2020

(c) The Author(s) 2020

\begin{abstract}
There are important studies that have directly focused on how, in times of conflict, it is possible for previously law abiding people to commit the most atrocious acts of cruelty and violence. The work of Erich Fromm (Escape from Freedom), Hannah Arendt (Eichmann in Jerusalem), Zygmunt Bauman (Modernity and the Holocaust) and Ernest Becker (Escape from Evil) have all contemplated the driving force of aggression and mass violence to further our understanding of how people are capable of engaging in extreme forms of cruelty and violence. This paper specifically addresses these issues by focusing on C. P. Taylor's play Good. This provocative play examines how a seemingly 'good' and intelligent university professor can gradually become caught up in the workings of the Third Reich. Taylor highlights the importance of appreciating how people can be steadily incorporated into an ideologically destructive system. I argue that the theatre is a powerful medium to explore these complex issues. The audience of Good find themselves confronted with the following question-'What would you have done?'
\end{abstract}

Keywords Authoritarianism $\cdot$ Banality $\cdot$ Cruelty $\cdot$ Violence $\cdot$ Nazism

\section{Introduction}

Hannah Arendt is well known for her work on banality, thoughtlessness and evil. Her report on the trial of the German Nazi leader Adolf Eichmann controversially asserted that Eichmann was not the 'monster' he was assumed to be. Arendt claimed that it would be more accurate to describe him as a 'clown' rather than a 'monster' [1, p.54]. Eichmann was an efficient bureaucrat who obediently followed orders. As a $\operatorname{cog}$ in a large bureaucratic machine, Arendt argued that he was able to distance and distract himself from the consequences of his actions. After observing his trial, Arendt decided that Eichmann was actually 'terribly normal'. This is a terrifying

James Hardie-Bick

J.P.Hardie-Bick@sussex.ac.uk

1 University of Sussex, Brighton, UK 
conclusion. This means there are many others just 'like him', who would also act with the same unscrupulous determination [1, p.276]. This paper makes connections to Arendt's work by examining Taylor's play Good [2]. This powerful play provides a fictional representation of how a very 'normal' university professor becomes enmeshed in the inner workings of the Third Reich. The paper examines the complexities and contradictions that accompany such a destructive personal transformation. My overall intention is to highlight the continuing relevance of both Arendt and Taylor, who, in their own way, were both extremely concerned with what Waller [3] has described as the ordinariness of extraordinary evil.

\section{The Banality of Evil}

Research on extreme forms of mass violence and human suffering has shown how previously ordinary and reasonable people can commit atrocious acts of cruelty and violence [1, 3-7]. The question of how this transition occurs has been documented by a number of theorists. For example, Erich Fromm's work on fascism detailed the social-psychological benefits of identifying with Nazi ideology [8]. When people submit themselves to a powerful and all-encompassing belief system they gain a sense of superiority over 'others' who remain unincorporated into the newly defined 'us'. Building on many of Fromm's insights, Ernest Becker addressed the importance of recognising how acts of cruelty and mass violence can be viewed by perpetrators as 'necessary' in order to create a more 'desirable' future [9, 10]. Becker's research focused on the inter-connections between idealism, mortality awareness, symbolic immortality and evil, and explored the importance of understanding the motivations behind the desire to create a 'perfect' society. Central to both Fromm and Becker is their insistence of the importance of conscious and unconscious motivation. People do not necessarily understand why they act in particular ways or why they have certain beliefs, values and desires. People can also deceive themselves about their own intentions. Fromm stated that it was Freud's insights into the workings of the unconscious that opened up a vast 'new world' and taught him that 'we are conscious of only a small part of ourselves' [11, p.66]. Freud [12-15] believed that there are many parts of our beliefs, feelings, desires and behaviour that escape conscious awareness. In addition to this, he maintained that the unconscious allows people to repress deep feelings of guilt, hatred, aggression, envy and shame. Fromm and Becker shared Freud's belief that people are not 'gentle creatures' who only 'defend themselves if they are attacked' [16, p. 302]. The psychoanalytic work of Freud, Fromm and Becker has shown how people are capable of perpetrating 'deeds of cruelty, fraud, treachery and barbarity' that are 'so incompatible with their level of civilization that one would have thought them impossible' [17, p. 280].

Zygmunt Bauman has also been influenced by Freud and his sophisticated social analysis has incorporated Fromm and Becker's psychoanalytic insights in relation to aggression, cruelty and violence. His work has been particularly influential to debates concerning mass violence and human suffering. In Modernity and the Holocaust he focused on how the Holocaust should be viewed as a specifically modern phenomena [18]. As Bauman argues: 
What we learned in this century is that modernity is not only about producing more and travelling faster, getting richer and moving around more freely. It is also about - it has been about - fast and efficient killing, scientifically designed and administered genocide [19, p.193].

Whilst Bauman was fully aware of the importance of Fromm and Becker, his work can be seen as being particularly influenced by Hannah Arendt [1]. Arendt's report on Eichmann showed how extensive documentation and bureaucracy protects people from having to confront the consequences of their actions and can facilitate mass murder. Arendt and Bauman argue that men and women can be responsible for the most inhuman and inexcusable actions 'without feeling in the least inhuman themselves' [19, p. 197].

Arendt is especially known for her controversial arguments concerning banality and evil. In her book 'Eichmann in Jerusalem: A Report on the Banality of Evil', she argued that Eichmann, who was personally responsible for the logistical arrangements for the Final Solution, should be seen as a clown [1]. The man responsible for the deaths of millions of men, women and children was no more than a petty bureaucrat who prided himself on successfully following orders and detached himself from the consequences of his actions. As Arendt notes, he would have only 'had a bad conscience' if he had not successfully followed his orders 'with great zeal and the most meticulous care' [1, p. 25]. Eichmann was able to deceive himself and Arendt argues that self-deception was a psychological survival strategy used by millions of people in Nazi Germany. Arendt understands evil as thoughtlessness. She claimed that Eichmann knew what he was doing, but that he did not think about his actions. Whilst Bauman is very supportive of Arendt's work, he is critical of her approach to evil and thoughtlessness:

My quarrel with Hannah Arendt...concerns her thesis of the 'banality of evil'. Arendt unpacks that baffling phrase as a charge of thoughtlessness: Eichmann was evil because he did not think. But it would be a hard task to prove Eichmann's thoughtlessness...Eichmann was a tremendously successful high-ranking bureaucrat, showered with medals and prizes for the efficiency of his thinking...Had Hitler emerged victorious from the war, universities would compete to have Eichmann among their teachers of managerial science. [20, p. 56].

Whilst Bauman is right to state that Eichmann was a thoughtful, ambitious and efficient bureaucrat, this does not completely undermine Arendt's argument. Focusing on how to successfully follow orders allowed Eichmann to compartmentalise his behaviour and divert attention from the consequences of his actions. When Eichmann researched the different methods of killing used by Nazi soldiers, including mass shootings and mobile gassing units, he was shocked by what he saw. It was all too much for Eichmann: 'I hardly looked. I could not...I had had enough. The shrieking...I was much too upset' [1, p. 87]. According to Erber, 'Eichmann was appalled at what he saw. He could not bear the sights of people being loaded onto the gassing trucks' and 'went to the back of the line when the commander at Treblinka gave a demonstration of the gas chambers' [21, p. 288]. Although he was fully aware his actions would result in the death of millions, on an everyday basis, he 
did not have to witness the millions who were murdered. He could distract himself in the specific details of his tasks rather than fully acknowledging and contemplating the death and human suffering he was responsible for. Eichmann compartmentalised mass murder. As Caswell has argued, the 'essential distinction is not between knowing and not knowing' about atrocities, the distinction is 'between knowing and thinking' [22, p. 22].

\section{The Evil of Banality}

The title of Minnich's study of evil reverses the title of Arendt's book, and she is well qualified to make this change. In The Evil of Banality [23] Minnich explains how she was Arendt's teaching assistant during the controversy surrounding Arendt's work on banality and evil. Minnich accompanied Arendt to many impassioned discussions and debates about the book. She was surprised by the amount of negative responses Arendt received: 'it was not only that there was a lot of disagreement that struck me; it was how vitriolic and highly personalized it often was' [23, p. 8-9]. The idea that Eichmann's crimes could be described as banal, and that Eichmann was not a monster, was too much for many people who attended her talks. The evil of the Holocaust was 'unthinkable'. Contrasting this unspeakable horror with banality provoked a great deal of outrage. Minnich believed that much of this hostility was understandable and could have been reduced if Arendt had talked about the evil of banality rather than the banality of evil:

Reflecting on Arendt's work and its early reception by good people who were deeply pained, I found myself reversing her [in]famous phrase and, having done so, thinking that perhaps it would have helped had she spoken, as she did not, of the 'evil of banality,' rather than - or, as I now think, in addition to 'the banality of evil' [23, p. 9].

This change shifts attention to the many convenient everyday banalities that people rely on to distract themselves from being attentive and reflective about wider social, cultural, economic and political issues. It is possible to justify indifference and apathy. Conventional justifications include 'it's none of my business' or 'no-one else is doing anything' or 'nothing I can do would make any difference'. Perhaps you 'don't want to put your head above the parapet' or 'lose the chance of being promoted at work'. There are many conventional ways people can justify their thoughtlessness and successfully avoid what Arendt described as thinking.

These conventional banalities are especially relevant when people are confronting what Minnich describes as extensive rather than intensive evil. This is an important distinction. Intensive evils refer to:

Great harms done by one or a few people. In that sense, they are contained: they stand in shuddering contrast with the lives others are leading around them in their times. When they burst into our lives, almost all of us are genuine spectators, not participants, not enablers, not perpetrators [23, p. 87]. 
Examples of intensive evil include serial killers, rapists, murderers and terrorists. All of these crimes are terrifying and shocking to members of conventional society. They provoke outrage. But such horrific acts should not distract our attention from what Minnich refers to as extensive evil:

Extensive evil is not contained; it is widespread. It does not stand out in stark contrast to persistent ordinary lives, normally decent people; it is enabled by the turning of whole systems until it is ordinary to do terrible things, to benefit, or go on living as if 'We didn't know.' Extensive evil requires that it be conventional to do its work as one's job, daily, day after day after day after day, with supper at home and picnics on the weekend [23, p. 88].

Unlike intensive evils, extensive evils are enabled by familiar and conventional motivations including careerism, social conformity, fear and greed. These motivations are normalised by society and disseminate a 'malignant normality' [24]. Unlike intensive evil, extensive evil focuses on the many, not the few. Extensive evil 'requires that uncomfortable shift' [23, p. 99]. These are 'the massive, monstrous harms carried out by many, many people for significant periods of times - months, years, decades and more' [23, p. 88].

\section{The Continuum of Destruction}

Extensive evil requires people to adapt and Staub's research on the continuum of destruction is also important [7]. Staub examines how the accumulation of events can incorporate people into a destructive social system. Even 'seemingly insignificant acts' such as the use of particular greetings, where to shop, or who you decide not to invite to a dinner party can legitimise and uncritically reinforce certain ideological beliefs. Staub identifies a gradual progression and highlights how people learn and subsequently change their beliefs and behaviour. As he states, 'initial acts that cause limited harm result in psychological changes that make further destructive actions possible' [7, p.17]. In addition to this, Staub draws attention to occurrences of 'just-world thinking', a process that helps inoculate people from sympathising with the victims. People are able to rely on just-world thinking to convince themselves that bad things do not happen to good people. Just-world thinking protects people from having to stand out from the crowd and encourages indifference. As bystanders and perpetrators learn to devalue and dehumanise victims, a reversal of morality can occur. Not only are deeply held beliefs concerning the welfare of others neglected, but a desire to hurt, humiliate and kill can be supported and encouraged. This reversal of morality urges perpetrators to become more able and willing to act against victims' and to develop a 'powerful commitment to genocide or to an ideology that supports it' [7, p.18].

Two important studies by Lifton [6, 25] clearly document how new group norms can emerge, and how perpetrators learn and dramatically change their beliefs and behaviour. His well-known study of Vietnam veterans highlights how soldiers initially found themselves in an extremely frightening, confusing 
and hostile environment [25]. The men were thrown into a world where extreme forms of brutality were normalised and celebrated. Examples of Staub's 'reversal of morality' and 'just-world' thinking are provided throughout Lifton's work. In Vietnam it did not take long for the soldiers to adapt to the extreme callousness displayed toward the Viet Cong:

They quickly became aware of random killing: "If you can shoot artillery and bombs in there every night," one of the men was quoted as saying, "how can the people in there be worth so much?" Still more graphic was the sight of a troop carrier driving by with "about twenty human ears tied to the antenna." The men were at first shocked ("It was kind of hard to believe. They actually had ears on the antenna"), but not long afterwards some of the men, having spotted a few Vietcong and called in the artillery, came back with an ear of their own, to the approval of their commanding officer. Others began to mark their estimated kills with notches on their rifles. The imagery is that of the hunt. The 'animals' one shoots serve merely to provide trophies, evidence of one's prowess.

[25, p. 44-45].

Another difficult, insightful and disturbing study is provided by Lifton's research on Nazi doctors [6]. This study further documents how people can learn to accept and justify the most extreme forms of human cruelty. The doctors who worked in the Nazi concentration camps played a vital role as they were responsible for selecting who should be sent to the gas chambers. The doctors determined the amount of gas to be used and would ensure that all the people in the chamber had been killed. In addition to this, the doctors were responsible for giving lethal injections and carrying out medical experiments on prisoners. Lifton's research documents the initial shock doctors experienced when they first arrived at Auschwitz. It is both troubling and surprising how quickly the doctors adapted to this environment. Lifton describes how doctors experienced an 'extraordinary individual-psychological shift from revulsion to acceptance' [6, p. 195]. The malignant Auschwitz environment forced the doctors to adapt: 'In the beginning', one of the doctors stated, 'it was almost impossible. Afterward it became almost routine. That's the only way to put it' [6, p. 195]. Various justifications and rationalistions were used by the doctors to 'minimize psychological discomfort and responsibility' [6, p. 213]. For example, many doctors convinced themselves that the gas chambers actually saved the inmates from unnecessary suffering. Another strategy involved the doctors focusing their attention on the technical problems involved in the killing process. The doctors were concerned about making the killing as 'humane' and 'efficient' as possible. Lifton shows how the personal 'transition from feeling to not feeling' was both 'rapid and radical':

In discussing patterns of diminished feeling, Ernst B [an SS doctor] told me that it was the "key" to understanding what happened in Auschwitz. In also pointing out that "one could react like a normal human being in Auschwitz only for the first few hours," he was talking about how anyone entering the place was almost immediately enveloped in a blanket of numbing. [6, p. 443]. 
The doctors socialisation to Auschwitz ensured their responsibilities became routinized. Lifton's research directly examines how it was possible for doctors to work in this unspeakably cruel environment and still be able to return home as loving husbands and fathers. Lifton documents the psychological transitions that enabled SS doctors to adapt and how they developed what he terms the 'Auschwitz self'. As he states, the Auschwitz self 'so violated the Nazi doctor's previous self-concept as to require more or less permanent disavowal [6, p.422]. The Auschwitz self allowed doctors to avoid 'feelings of guilt' so they could 'engage in medicalized killing, an ultimate form of numbed violence' [6, p.442].

\section{C.P. Taylor's Good}

Many of the themes addressed in the work of Arendt, Bauman, Minnich, Staub and Lifton are explored in Taylor's play Good [2]. This remarkable play, set in pre-war Germany, focuses on an unassuming and well-intentioned university professor who becomes fully enmeshed in the internal workings of the Third Reich. The main protagonist is John Halder. He is in his early forties and is a lecturer in German literature. Halder is married with three children, works in Frankfurt and, most importantly, has written a novel about euthanasia. This novel is based on his personal experiences with his Mother's senile dementia. One of Halder's most valued relationships is with Maurice, who Halder describes as his best friend. Maurice is a Jewish doctor. He trusts Maurice and openly talks to him about his personal problems and concerns. One of Halder's main problems is that whenever he contemplates difficult problems, his thoughts are accompanied by the sound of band music:

HALDER (to the audience) The bands came in 1933. So you can't say they came with the rise of the Nazis, exactly. The Nazis were on the rise long before that. To some extent, it was a device that was with me from childhood. Bringing music into the dramatic moments of my life. But from'33, they became an addiction. Jazz bands...café bands...tenors...crooners...symphony orchestras. Depending on the particular situation and my mood. [2, p. 1].

Halder is desperate to overcome his anxiety neurosis to improve his relationships both at work and with his family. He asks Maurice for advice and acknowledges his neurosis may be a survival strategy, a psychological defence mechanism that turns 'reality into fantasy'. Different types of music accompany Halder during the most tragic moments of his life and this anxiety neurosis distracts him from directly confronting the reality of each situation.

As I will later explain, the accompanying music becomes particularly significant at the end of the play. Throughout the play there are many competing, fragmented memories that Halder has about his wife, mother, children, girlfriend, Maurice and Nazi officials including Eichmann. These scenes run concurrently and interrupt one another, but essentially this is a play about the Holocaust and the rationalisation of evil. The play invites the audience to reflect on Halder's stream of consciousness and to consider the escalating commitments that lead to his dramatic transformation. 
At the start of the play we learn that Halder is someone who is very critical of the Nazi party. However, his novel on euthanasia captures the attention of Nazi Officials as it is recognised that Halder's support would provide credibility to Hitler's plans for racial purification. During a secret meeting with Over-Leader Bouller, Halder is informed that his novel has caught the attention of Doctor Goebbels, and that Goebbels himself was impressed by the novel. Even Hitler has read his novel and Halder is shown where Hitler had scribbled 'written from the heart' in the margins of his book. Halder's work is recognised and valued. In the role of a consultant, he is asked to write a paper that examines similar themes to his novel. The paper would need to justify the necessity of mercy killings and explain how this method of treating the 'incurable' and 'insane' is both compassionate and humane. Halder is persuaded and agrees to write this paper. As a consequence, Halder is offered new career opportunities, starts to question his previous views about Nazi ideology and eventually rationalises atrocities. The following scenes from the play, many involving events that took place in Nazi Germany, inform Halder's changing beliefs and rationalisations. Rather than providing a detailed synopsis of the play, my intention is to identify key scenes that capture Halder's personal transformation.

\subsection{Halder's Decent into Hell}

At the start of the play both Halder and his friend Maurice are very sceptical of Hitler. Maurice knows Germany relies on 'Jewish brains' and states that Hitler is 'bound to drop all that racial shit they had to throw around to get their votes' [2, p. 6]. Although, in his more rational moments, Maurice does not believe Hitler will follow through on his anti-Semitic programme, he is still extremely worried. Maurice is not at all confident that Hitler fully understands the impracticality of his ideological beliefs. Whatever happens, Maurice knows Halder will be able to continue living a safe and secure life. Here we have two friends who find themselves in very different circumstances. Even if Hitler pursues his anti-Jewish progamme, Halder could still live in Frankfurt, work as a professor or even become the Vice Chancellor of the University. Unlike his friend, Maurice is now forced to live with unprecedented levels of uncertainty and anxiety. Halder tries to reassure Maurice. He tells him not to worry about the propaganda. Hitler's racialist programme is not at all practical:

HALDER: I'll get you a drink, Maurice...Relax... You're right...All that antiJew rubbish... You're right...Just balloons they throw up in the air to distract the masses... You're right.

MAURICE: I know I'm bloody right. I'm telling you... But my bloody anxiety neurosis has fixed on to it.... and I can do shit all about it...

[2, p. 6-7].

Taylor is right to emphasise this particular attitude. In the gradual build up to Hitler taking power many respected commentators, including the French ambassador Andre Francois-Poncet, remained critical of Hitler and did not take him too seriously. Like Halder, Francois-Poncet was not particularly worried and thought Hitler's influence was declining [26]. It is also worth noting that in 1933 
Jean-Paul Sartre was living in Berlin, studying the philosophy of Husserl. Even though this was only nine months after Hitler was elected, Sartre was 'not particularly sensitive' to Hitler's rise to power, and was busy studying phenomenology amidst street demonstrations and increasing levels of violence [26, p. 97]. When asked about his time living in Berlin, despite acknowledging the Nazi presence, he still described this time as 'a very happy year' [27, p. 26]. In 1933 there were many journalists and political commentators who believed that Hitler would soon disappear from the political arena [26].

\subsection{Joining the Nazi Party}

Halder does not think Maurice should be overly concerned about the Nazi propaganda, and like Maurice, he is also very critical of Nazi ideology. But Halder is soon pressurised by his wife Helen, and his father-in-law, to join the Nazi party. Helen urges Halder to join, to ensure all the family are safe. She states that her father intends to talk to him about joining the National Socialists. Not only would his university career be thwarted, but according to Helen's father, he may even lose his lectureship at the university if he decided not to join the party. Although he has reservations, Halder reveals his decision to Helen:

HELEN: I assumed, in the end, you'd be sensible.

HALDER: I'm doing it because I love you...you know that. If it was just myself, I'd take a chance. I'm not one hundred per cent sure about Hitler... you understand that...I love you and the children...

[2, p.19].

In another scene with Anne (student/girlfriend) he takes a different approach to justify this decision. Halder explains that Hitler may think that Germany should exclude the Jewish population, but 'in reality', Jewish scientists, doctors, chemists and capitalists are all part of German culture. Perhaps, he suggests, people like himself and Anne actually have a responsibility to join the party:

HALDER. It's not only survival, is it? Joining the Nazis. If people like us join them...instead of keeping away from them, being purist...And pushed them a bit towards humanity...Is that kidding yourself?

ANNE. What if they push us the other way?

HALDER. Yes...it could happen... Yes...If it did...I'd get out... No question about it...I'd pull myself away...I'd get out of the country...We'd get out of the country...

[2, p. 26].

Halder decides to join the party to protect his family and further justifies his decision as an attempt to shift the party to a more reasonable and humane position. Maurice remains entirely unsympathetic:

MAURICE: You joined the Nazis! You...For fuck's sake.

HALDER: I told you I joined the Nazis... 
MAURICE: The reality is coming to me...Jesus...Johnnie...God in heaven. [2, p. 17].

\subsection{The Nazi Book Burning}

On the 10th May 1933 one of the most famous Nazi book burnings took place in Opernplatz, Berlin. The book burnings were organised by the National Union of Students who decided to take action against what they considered to be 'un-German' books. Ritualised ceremonies with speeches and light processions occurred throughout Germany. In Opernplatz over 25,000 books believed to be contaminating the German spirit were set on fire by students, professors and members of paramilitary organisations [28]. Many famous national and international authors were targeted including Sigmund Freud, Heinrich Heine, Ernest Hemmingway, Hermann Hesse, Jack London, Thomas Mann, Karl Marx, Robert Musil and Leo Tolstoy.

In the play, the SS Major known as Freddie informs Halder that he has a new order for him. Freddie is apologetic. As Halder is a university lecturer, he does not think Halder will approve. Halder reads the order and learns that he has to organise a book burning ceremony at the university. Freddie knew Halder had 'deep feelings about books' and believed the order would 'cut him deeply' [2, p. 38]. However, rather than being critical, Halder remains optimistic:

HALDER (to himself): There's a positive aspect to all this. You've got to make a supreme effort and look positively... One of the basic defects of university life is learning from books. Not from experience...Life...involvement...commitment...agony and panic at being thrown into the storm that's the human condition...

FREDDIE. Mind, I can see what they're getting at, burning Freud's filthy shit. Pervert isn't he? Tried to make out everybody's as twisted and perverted as he is!

HALDER (to himself): If you looked at it from the philosophical standpoint, that the burning is symbolic of a new healthy approach to university learning... Man does not live by books alone.

[2, p. 38-39].

Even though Halder has read and respects some of the authors on the list of books to be burned, he rationalises the event by viewing it symbolically. He informs Freddie that he will not be burning his own copies. For Halder, the book burning ceremony represents a new start, an existential challenge to the traditional pedagogical approach to learning. This is a ceremony that will celebrate a different approach to teaching and learning and will unlock new opportunities for Germany. 


\subsection{The Night of Broken Glass}

The Night of Broken Glass, another key scene of the play, describes the violence directed against the Jews on November 9, 1938. This event, known as Kristallnacht, was named to reflect the amount of shattered glass on the streets of Germany. Organised by Joseph Goebbels, this violence was directed against both Jewish businesses and Jewish people. Over the course of two days over 7000 businesses were vandalised and looted, 250 synagogues were attacked and burnt and Jews were killed. Jewish homes, schools and cemeteries were targeted. Despite the mass violence and fires, the police and fire brigades did not intervene. Directly after the violence, around 30,000 Jewish men were arrested and taken to concentration camps, and the remaining Jewish population had to abide by strict curfews that restricted their freedom of movement. After Kristallnacht businesses managed by Jews were forced to cease trading. The Jewish population were now systematically stigmatised and segregated from all areas of everyday life in Germany [29].

In the play Halder is conflicted and troubled by the violence. He knows that Jews will be attacked and arrested and that houses, businesses and synagogues will be targeted. As Halder states, there are 'roughnecks in the Party' and 'Excesses are bound to happen' [2, p. 57]. Whist he knows that targeting a racial group is 'not a good thing', Halder thinks it is necessary to look at this violence 'in perspective'. Halder convinces himself that the violence is necessary:

HALDER. I see tonight...As a basically humane action...it's going to shock the Jews into the reality of their situation in Nazi Germany... Tomorrow morning... They'll be running for their lives out of the country.

...A sharp, sudden shock...that is going to make those who still delude themselves that they can stay here in peace to face reality...

[2, p. 57].

Halder justifies the violence as this will alert Jews to the seriousness of their situation. At the same time he is also becoming very critical of the Jews for not taking responsibility for their own lives and leaving the country. At this stage of the play he has abandoned his friend Maurice. Maurice asks Halder to obtain the necessary exit papers for him so he can leave Germany:

MAURICE. Get me these exit papers, then, Nazi cunt! Fucking do something about this fucking great friendship, then for fuck's sake!

[2, p. 32].

Halder refuses. Despite their friendship, he is not willing to take the risk of being sent to prison. He has too many people depending on him. Recognising that Halder will not help with the exit papers, Maurice asks him to buy five train tickets to Switzerland instead. Halder refuses to buy the tickets and reminds Maurice he is an SS officer. Once again, Halder tries to reassure Maurice that 'this is a temporary racist aberration' and that no-one 'takes that metaphysical racialist rubbish in Mein Kampf seriously' [2, p. 48]. Maurice no longer believes him. He knows new laws are about to be introduced. He also realises that Halder is not prepared to help him. 


\subsection{At the gates of Auschwitz}

Towards the end of the play Halder has a meeting with Eichmann. Eichmann comments on how Halder has been an 'excellent comrade' as both a 'university man' and a 'compassionate' S.S. officer. He states that he would like Halder to work closely with him. His responsibilities would involve writing reports about the 'leadership, morale...amenities' and 'the general situation' at some of the concentration camps. Eichmann needs a reliable report that evaluates 'the recommendations for the processing of the diseased and the unfit' [2, p. 64]. He also expects Halder to report on any 'unnecessary cruelty' or 'sadistic behaviour' that could have 'a disastrous effect on the general level of discipline' [2, p. 64]. Eichmann informs Halder that a sabbatical has been arranged for him so he can carry out this work away from the university. Halder agrees to write a report for Eichmann. In the final scene of the play Halder arrives at Auschwitz and is greeted by the camp commandant Hoss:

HALDER (to the audience): He showed no emotion. That was it. Might have been some mental condition. On the other hand, just stress...the poor bastard had a hell of a job...He did make a supreme effort and smiled.

The funny thing was...I heard this band. Playing a Schubert March. 'Oh,' I registered to myself. 'We're having Schubert, now.'

...Then I became aware that there was in fact a group of prisoners...Maybe in my honour. I'm not sure...The important thing was...The significant thing: the band was real.

Up band...HALDER watching them...

...The band was real!

[2, p. 69].

Throughout the play Halder's problems and dilemmas have been accompanied by imaginary bands. A tenor may suddenly appear in his office, a band or a jazz trio may start playing and such music interrupts and accompanies some of the main scenes in the play. At the end of the play, Halder is standing in his SS uniform with Hoss at the gates of Auschwitz. This is where the music in his imagination stops. This powerful concluding scene draws attention to how both amateur and professional musicians played concerts at Auschwitz. Although musicians could organise concerts for the other prisoners, they were mainly forced to play concerts for the S.S. officers. They could also be forced to play during public punishments, executions and the so-called selection process [30]. In this final scene the illusory musicians who constantly disturb Halder's existence are replaced by a real orchestra. The imaginary musicians that psychologically protected Halder from having to face reality have been replaced. The psychological mechanism that transformed reality into a fantasy has ensured that his personal fantasies have become reality. 


\section{Discussion}

Good is an extraordinarily powerful play. Whilst there are many different, interweaving and fragmented narratives, the examples cited above are all significant and capture Halder's transformation. In his meeting with Over-Leader Bouller, Halder is flattered by the attention and praise his novel on euthanasia has received from both Dr Goebbels and Hitler. He is seen as an important academic who has the ability to discuss complicated moral questions. He is also reassured about the intentions of the Party, as his work is valued for being compassionate. After agreeing to write a paper on the necessity of mercy killings, Halder is gradually drawn deeper within the workings of the Nazi party. Later in the play, Eichmann flatters Halder by stating that he needs a report on the concentration camps that he can trust. Taking a similar approach to Bouller, Eichmann reassures Halder's conscience by explaining that they are not 'monsters' and that he requires an honest report that would include accounts of any cruelty. As Eichmann states, he wants 'the same human, without sentimentality approach' [2, p. 64] that Halder has become known for. Halder agrees to work for Eichmann and this justifies the final dramatic scene with Hoss at the gates of Auschwitz. At the beginning of the play Halder is a lecturer in German literature who has written a novel about euthanasia. By the end of the play Halder is an SS officer working for Eichmann at Auschwitz.

There are significant changes in the way Halder views the beliefs of the Nazi party and the increasing violence against the Jewish population. At the start of the play he is critical of Hitler and the Nazi party. Although he decides to join the party, he does so reluctantly, mainly under the relentless pressure from his wife and father-in-law. But this is not enough. He needs to have his own personal reason to join the party. This is reflected in his discussion with his girlfriend Anne. If more people like 'us' joined, Halder reasoned, then all the anti-Jewish propaganda would be abandoned. Later on in the play, it is Anne who is reassuring Halder, as she helps him into his SS uniform for his duties during Kristallnacht. The Party did not abandon their anti-Jewish agenda, and Halder and Anne are not leaving the country, as they previously said they would. Indeed their own guilt about the plight of the Jews is somewhat avoided as they have both started to blame the Jews. Kristallnacht is viewed by Halder as a humane action as the violence will alert all the remaining Jews that they really do need to leave Germany. The violence is justified.

His relationship with his best friend Maurice further documents Halder's transformation. At the beginning of the play Halder is critical of Nazi ideology. Of course, unlike Maurice, Halder is in a very different position as his life is not under threat from the anti-Jewish programme. Halder tries to reassure Maurice that their analysis is right, and that Hitler is bound to 'drop' all the anti-Jewish propaganda. Here we can assume that Halder is being honest. As I have discussed, in the early 1930s many political commentators believed that Hitler's influence would decline. Nevertheless, Halder continues to try to reassure Maurice when it is very clear that his life is under threat. Rather than deliberately lying to Maurice, he has started to 
deceive himself. Halder is defending himself from a truth he cannot face. Even when it is clear that new legislation is about to be passed, Halder still maintains that Hitler will not survive. However, Halder is not entirely convinced by his own deceptions. At the same time as providing reassurance, Halder is having his own personal doubts. His internal dialogue constantly shifts and contradicts his advice to Maurice. His attempts to deceive himself are not enough to combat his reoccurring panic and doubt. He still panics and questions himself about whether Germany has been turned into a prison. He still occasionally thinks about the possibilities of leaving the country. Towards the end of the play his self-deceptions are reinforced by placing blame directly on the Jewish population. Anne both shares and fortifies this view:

ANNE. In any case, for God's sake...If I was Jewish I'd have got out of here years back... The first year Hitler was in power... Any Jew with sense is out by now... The ones that are left must be utterly stupid or desperate to hang on to their property... What are they doing staying in Germany?

HALDER. Listen. You're so clever. You're right. Everything you say is so logical and true.

[2, p. 62-63].

Halder now believes the Jews should have left Germany when they still had a chance to leave. After Halder agrees to write a report on the concentration camps for Eichmann, Maurice appears in one of Halder's imaginary bands. Halder speaks to the audience and states that Maurice had disappeared 'months ago'. But Maurice is now there in front of him conducting a choir. He wants to talk to Maurice. He tells Maurice that the Jews are responsible for pushing Germany into this situation. Maurice responds: What's he saying? What is this shithead talking about? It's my fault, his fucking machine-guns mowed me down? [2, p.66]. In this last scene between Halder and Maurice, despite blaming the Jews for creating such a nightmare in Germany, Halder says he forgives Maurice.

Throughout the play Halder is reassured he is a good person. Whether it is in conversation with Eichmann, Bouller, Maurice, Helen or Anne, he likes to be seen as a 'good', caring and compassionate person. He also has difficult discussions with Maurice and has serious doubts as to whether he is making the right decisions. Halder is not an evil, cruel, unremorseful psychopath. As Arendt would argue, Halder, just like Eichmann, is terrifyingly normal:

The trouble with Eichmann was precisely that so many were like him, and that the many were neither perverted nor sadistic, that they were, and still are, terribly and terrifyingly normal. From the viewpoint of our legal institutions and of our moral standards of judgement, this normality was much more terrifying than all the atrocities put together, for it implied...that this new type of criminal...commits his crimes under circumstances that make it well-nigh impossible to know or to feel that he is doing wrong [1, p. 276].

Halder is certainly not sadistic and in this respect he can be viewed as belonging to the 'new' type of criminal described by Arendt. Halder's reports developed a reputation that impressed the top echelons of the Nazi Party. His decisions ultimately 
increased his job security and social status. Towards the end of the play it is clear that he has taken a Jewish professor's job at the university and lives in a large house. Nevertheless, Halder's circumstances did not alleviate his reoccurring doubt and uncertainty, and it was certainly not 'well-nigh impossible' for Halder to feel that he was 'doing wrong'. Halder is constantly panicking and doubting himself. His internal dialogues are often contradictory, at times he 'loves' the Jews, at other times he blames the Jews. Indeed, throughout the play he is confronted by imaginary bands precisely because of the difficult problems he is forced to confront. Halder compartmentalises his behaviour and relies on the everyday conventional banalities identified by Minnich [23]. But Arendt is right to highlight the necessity of self-deception. Whether it was joining the Nazi party, writing reports for Bouller and Eichmann, organising a book burning at the university, or betraying his friend Maurice, Halder is always attempting to rationalise his behaviour to demonstrate to himself and to others that his intentions are reasonable, understandable and ultimately good. Yet Halder never seems totally persuaded by his rationalisations, and feelings of doubt, panic and guilt are never far from the surface. The final scene between Anne and Halder captures this uncertainly. Anne is trying to reassure Halder: 'Whatever happens', she states, 'However we get pushed...I know we're good people... both of us'. 'Yes', Halder replies 'We probably are...good...Yes...Whatever that means. [2, p. 68].

\section{Conclusion}

Good is a play about an ordinary university professor who gradually becomes a committed Nazi. As Freud rightly noted, atrocious 'cruelties and injustices' can occur in 'the most civilized nations', and as this play demonstrates, perpetrators will often display 'a general lack of insight' into the nature of 'their own lies and wrongdoings' [17, p. 301-302]. Whilst Good is directly about Nazi Germany, the importance of the play is clearly not restricted to that particular period of time. We may live in highly cultured and liberal societies, but we also have to live with the unsettling knowledge that extreme forms of violence and intolerance can rapidly become normalised. The malignant normality of extensive evil could yet again return to pervade our everyday lives. And the perpetrators are not likely to be the easily distinguishable evil perpetrators we may assume them to be. Although in the final scene of the play Halder is working at Auschwitz, he is not a sadist or an uncontrollable and vindictive psychopath. As Arendt would argue, it is far worse than that. Halder is actually terrifyingly normal. Reflecting on his interviews with Nazi doctors, Lifton [6] commented on the distressing normality of his interviewees. Even though there is nothing psychologically 'darker or more menacing, or harder to accept, than the participation of physicians in mass murder' [6, p. 3], he found that Nazi doctors could be polite and amicable. Lifton admitted to struggling with this throughout his research:

What I have struggled with throughout this study-is the disturbing psychological truth that participation in mass murder need not require emotions as 
extreme or demonic as would seem appropriate for such a malignant project.

Or to put the matter another way, ordinary people can commit demonic acts $[6$, p.5].

The first Nazi doctor he interviewed greeted him in a friendly way and he could remember feeling that it was pleasant to spend time with this 'likeable' man. He remembers being immediately horrified by his thoughts and having to remind himself that 'this bastard is one of them!' [31, p. 263]. Lifton found it hard to accept that it is not only 'monsters who perpetrate monstrous deeds' [32, p. 23]. It is this disturbing realisation that explains why Taylor's play is so powerful and provocative. The play forces the audience to ask questions about social conformity, fear, social status, loyalty, friendship and personal responsibility. The theatre is an important medium for exploring these issues as the audience are encouraged to assess what choices they would have made in Halder's situation. The 'lesson to be learned', Taylor argued, and what the play directly reveals, is that the atrocities of the Third Reich are not to be explained as a 'simple conspiracy of criminals and psychopaths'. The atrocities are rather 'the result of the infinite complexity of contemporary human society' [33].

Good is not a play about monsters or psychopaths. Good is also not a play about automatons who are able to function as well-oiled cogs in the machine. Throughout the play Halder is troubled by his actions. Despite his increasingly sophisticated excuses and rationalisations, Halder constantly doubted himself. Even after he started to blame the Jews for their own predicament, there are still glimmers of insecurity and doubt concerning the validity of his arguments. As his commitments to the Nazi regime escalated, his rationalisations served an important psychological function. They did not completely remove his uncertainty. Nevertheless, they were convincing enough for him not to resist or attempt to flee the country. They were persuasive enough not to risk helping his best friend. They were strong enough to say 'yes' to both Bouller and Eichmann. His rationalisations to excuse the inexcusable were also credible enough to believe he was 'probably' still a good person.

The play challenges the view that perpetrators are guilty of thoughtlessness. Bauman was right to critique Arendt by emphasising that Eichmann was a highly successful bureaucrat. High-ranking officials are likely to be ambitious and thoughtful individuals who value efficiency and innovation. As Vetlesen [34] argues, Arendt assumed that thinking was necessarily good. She did not explore the connections that exist 'between thinking and evildoing'. She did not consider the hypothesis 'that thinking may actively side with, or even produce, evil' [34, p. 60]. Whilst this is an important criticism of Arendt, these arguments do not invalidate her claims in relation to thoughtlessness. They do, however, suggest that Arendt should have been more precise. Arendt was specifically focusing on how Eichmann distracted himself from reflecting on and thinking about the consequences of his actions. In the play Halder is certainly thinking. He makes decisions, attends meetings, writes reports, and creates defensive rationalisations. Being thoughtful, in this more general sense of the term, can certainly be responsible for evil. Yet Halder was trying, and not always succeeding, to avoid thinking 
about the victims of Nazi ideology. His rationalisations were important defensive strategies to assist his own self-deception. As Arendt maintained, this is a key psychological survival strategy. Halder could not be accused of thoughtlessness, but he was able to distract himself. He did not have to think too deeply about the full consequences of his actions.

To conclude it is worth remembering Bruno Bettelheim's pessimistic warning. Bettelheim, himself a survivor of Dachau and Buchenwald concentration camps, analysed the behaviour of his fellow prisoners. He was determined to learn about how people react to such extreme situations. He argued that when people are placed under great stress, 'most people are neither heroes or martyrs'. Unfortunately, when placed in these circumstances, most people 'deteriorate rather rapidly' [35, p. 261-262]. A similar point is emphasized by Snyder:

Most of us would like to think that we possess a 'moral instinct'. Perhaps we imagine that we would be rescuers in some future catastrophe. Yet if states were destroyed, local institutions corrupted, and economic incentives directed towards murder, few of us would behave well. There is little reason to think that we are ethically superior to the Europeans of the 1930s and 1940s, or for that matter less vulnerable to the kind of ideas that Hitler so successfully promulgated and realised [36, p. 320].

Taylor's play successfully questions whether we would be the 'rescuers' we like to imagine ourselves to be. Good encourages the audience to contemplate the 'ordinariness of extraordinary evil'. This is an important and necessary shift. Understanding the ordinariness of evildoing means that 'we will be less surprised by evil' and hopefully 'better equipped to forestall evil' [3, p. 297]. Of course, it is 'unbearably difficult' to see the potential 'for evil within ourselves' [32, p. 7]. Good is a remarkable play as it forces us to do just that. It is uncomfortable. It is also necessary. As Waller has argued, understanding 'our own capacity for evil...is the best safeguard we can have against future genocides and mass killings’ [3, p. xvii].

Open Access This article is licensed under a Creative Commons Attribution 4.0 International License, which permits use, sharing, adaptation, distribution and reproduction in any medium or format, as long as you give appropriate credit to the original author(s) and the source, provide a link to the Creative Commons licence, and indicate if changes were made. The images or other third party material in this article are included in the article's Creative Commons licence, unless indicated otherwise in a credit line to the material. If material is not included in the article's Creative Commons licence and your intended use is not permitted by statutory regulation or exceeds the permitted use, you will need to obtain permission directly from the copyright holder. To view a copy of this licence, visit http://creativecommons.org/licen ses/by/4.0/.

\section{References}

1. Arendt, Hannah. 1994. Eichmann in Jerusalem: A report on the banality of evil. New York, NY: Penguin Books.

2. Taylor, Cecil. 1982. Good. London: Methuen London.

3. Waller, James. 2007. Becoming evil: How ordinary people commit genocide and mass killing. Oxford: Oxford University Press. 
4. Zimbardo, Philip. 2007. The Lucifer Effect: Understanding How Good People Turn Evil. New York: Random House.

5. Haritos-Fatouros, Mika. 1988. The official torturer: A learning model for obedience to the authority of violence. Journal of Applied Social Psychology 18: 1107-1120.

6. Lifton, Robert. 2000. The Nazi doctors: Medical killing and the psychology of genocide. New York: Basic Books.

7. Staub, Ervin. 1989. The Roots of Evil: The Origins of Genocide and other Group Violence. New York: Cambridge University Press.

8. Fromm, Erich. 1969. Escape from Freedom. New York: Henry Holt and Company.

9. Becker, Ernest. 1975. Escape from Evil. New York: The Free Press.

10. Becker, Ernest. 1997. The Denial of Death. New York: The Free Press.

11. Funk, Rainer. 2000. Erich Fromm: His Life and Ideas. New York: Continuum.

12. Freud, Sigmund. 1936. The Ego and the Mechanisms of Defence. London: Hogarth Press.

13. Freud, Sigmund. 1976. The Interpretation of Dreams. Harmondsworth: Pelican.

14. Freud, Sigmund. 1984. The Unconscious. In: The Pelican Freud Library. Vol. 11: On Metapsychology: The Theory of Psychoanalysis, 159-222. Harmondsworth: Pelican.

15. Freud, Sigmund. 2005. The Question of Lay Analysis. In The Essentials of Psychoanalysis, ed. A. Freud, 5-65. London: Vintage Books.

16. Freud, Sigmund. 1991. Civilization and its discontents. In: The Penguin Freud Library. Vol. 12: Civilization, society and religion: 'Group psychology', 'Civilization and its discontents', and other works, 243-340. Middlesex, UK: Penguin.

17. Freud, Sigmund. (1964) Thoughts for the times on war and death. In The Standard Edition of the Complete Psychological works of Sigmund Freud. Vol XIV On the history of the psycho-analytic movement Papers on metapsychology and other works, 273-302. London: The Hogarth Press.

18. Bauman, Zygmunt. 1989. Modernity and the Holocaust. Cambridge: Polity Press.

19. Bauman, Zygmunt. 1998. Life in fragments: Essays in postmodern morality. Oxford: Blackwell.

20. Bauman, Zygmunt, and Keith Tester. 2001. Conversations with Zygmunt Bauman. Cambridge: Polity Press.

21. Erber, Ralph. 2002. Perpetrators with a clear conscience: Lying, self-deception, and belief change. In Understanding genocide: The social psychology of the Holocaust, ed. L.S. Newman and R. Erber, 285-300. New York: Oxford University Press.

22. Caswell, Michelle. 2010. Hannah Arendt's world: Bureaucracy, documentation, and banal evil. Archivaria 70: 1-25.

23. Minnich, Elizabeth. 2017. The evil of banality: On the life and death importance of thinking. Lanham, MD: Rowman \& Littlefield.

24. Lifton, Robert. 2019. Losing Reality: On cults, cultism, and the mindset of political and religious zealotry. New York: The New Press.

25. Lifton, Robert. 2005. Home from the War: Learning from the Vietnam veterans. New York: Other Press.

26. Cohen-Solal, Annie. 1987. Sartre: A life Trans Anna Concogui. New York: Pantheon.

27. Geressi, John. 2009. Talking with Sartre: Conversations and Debates. New Haven: Yale University Press.

28. United States Holocaust Memorial Museum. "Book Burning." Holocaust Encyclopedia. https:// encyclopedia.ushmm.org/content/en/article/book-burning [accessed 12/11/2019]

29. United States Holocaust Memorial Museum. "Night of Broken Glass." Holocaust Encyclopedia. https://encyclopedia.ushmm.org/content/en/article/the-night-of-broken-glass [accessed 16/11/2019]

30. Laks, Szymon. 1989. Music of Another World. Illinois: Northwestern University Press.

31. Lifton, Robert. 2011. Witness to an Extreme Century: A Memoir. New York: Free Press.

32. Bauman, Zygmunt, and Leonidas Donskis. 2019. Moral Blindness: The Loss of Sensitivity in Liquid Modernity. Cambridge: Polity Press.

33. Taylor, Cecil. 1982. "Authors note" in Good. London: Methuen London.

34. Vetlesen, Arne Johan. 2005. Evil and Human Agency: Understanding Collective Evildoing. New York: Cambridge University Press.

35. Bettelheim, Bruno. 1979. Surviving and other essays. New York: Knopf.

36. Snyder, Timothy. 2015. Black Earth: The Holocaust as History and Warning. London: Bodley Head. 
Publisher's Note Springer Nature remains neutral with regard to jurisdictional claims in published maps and institutional affiliations. 